\section{Bootstrapping a new institute}

Bucharest. The jewel in the crown of the Romanian Academy of Sciences is the Institute of Cellular Biology and Pathology, run by the husband-and-wife team Nicolae and Maya Simonescu.

A thriving centre, with 130 staff, 50 of them scientists who have mostly worked abroad, the institute is one of the very few in Romania performing world-class research. It concentrates its efforts on the molecular and cell biology of the cardiovascular system, with particular reference to atherosclerosis.

The centre did not attain this position easily. Its present status is entirely the product of the determination of its director to provide a haven for good science in his home country despite the almost impossible political situation.

Nicolae Simonescu made his escape from Romania in 1970 when, after a year-long struggle, he got a visa to visit the United States. He spent the next three years as a research fellow at the Rockefeller University and then moved to Yale, where he eventually became a professor.

Despite his success across the Atlantic, Simonescu always wanted to return home to help make it possible to do good research work in Romania. In 1972, he sent the government a proposal for the building of an institute of cell biology, in which there were virtually no studies anywhere in Romania. His association with
George Palade, a Nobel prizewinner and Romanian expatriate, helped his cause; the following year, the government approved the proposal in principle.

Simonescu agreed to return to run the institute under certain very strict conditions, the most important being that he would be allowed to spend a part of each year in the United States, and that he would be able to send his young scientific staff there for training.

After numerous delays, during which decisions were repeatedly made and unmade, the institute, reasonably equipped, finally came into being in 1979 . The Simonescus came home. But they were immediately told by the Ministry for Health and Education that funds had run out. The institute would receive funds only for salaries and maintenance costs.

For the succeeding decade, the Simonescus survived on substantial grants from the United States - for a time, they were the only institute in eastern Europe to hold grants from the US National Institutes of Health - and brought vast shipments of equipment and journals back with them from their annual visits to the United States. Customs records show that, between 1979 and 1992, they transported $14,000 \mathrm{~kg}$ of material, worth US $\$ 33,000$.

In addition, Simonescu managed to send 16 young scientists to work in laboratories in the United States during the

\section{Taxing times for research funds}

For the first two years after the revolution, there was no government structure with specific responsibility for science. Elena Ceauşescu's hated National Council for Science and Technology had been abolished. Science was in a vacuum.

With the election of the second postrevolutionary government in 1992, a Ministry of Research and Technology was established. That, in turn, is now trying to develop a science policy. In time-honoured fashion, the ministry has created two advisory councils, one for applied and one for basic research, each of which includes a network of specialist committees drawn from the scientific community. The plan is to set research priorities and supervise research programmes.

The committees have not yet reached agreement on a general policy, but ideas include the establishment of a Romanian Fund for Science to provide Romania's first formal competitive project money, and the establishment of an interministerial Council for Science and Technology, to define research and development priorities and allocate funds accordingly.

Meanwhile and inevitably, the budget for science in Romania has fallen dramatically. In 1990, it was at its peak of 2.6 per cent of GNP, but by 1992 it had fallen to 1.7 per cent and is now around 0.6 per cent of GNP. The leader of one of the main parties in the governing coalition recently pledged support for an increase to 1 per cent, but it is understandable that the goal is, at present, unrealistic.

It is less understandable that the diminishing funds have been so disastrously administered. While the Romanian Academy has always had its own direct budget, more than half of the rest of Romania's research has been topped up by a 1 per cent tax on private and state companies, imposed in 1991. The tax was modelled on Ceauşescu's New Technology fund. In the event, in post-revolutionary Romania, the tax has proved impossible to collect. The result is that the research ministry has had to take out loans, which it can ill-afford, to pay its research institutes.

Mercifully, the government has agreed to comply with a strong World Bank recommendation that the tax be replaced next year by normal budget support. 1980s. Surprisingly, none defected: all returned to form the core staff of the institute.

The Simonescus established a number of traditions in their institute during the 1980 s, in defiance of the government. One was to require all scientists to give regular progress reports of their projects in English, to ensure that language did not become a scientific barrier. They also held regular US-Romanian scientific workshops, bringing in US scientists, using US money.

The Simonescus have sought to nurture a broader appreciation of culture. They play taped classical music concerts in the common-room with information sheets about the composer taped to the tables, and have used their auditorium to hold cultural, as well as scientific, events. They celebrate Christmas - complete with Christmas tree and Santa Claus - for the staff and their children and insist that everyone takes the day off.

These actions were regarded by the old regime as provocative, but they were tolerated. But as time went on, the institute began to be regarded with more and more suspicion by Ceausescu, culminating in his declaration in September 1989, at the height of his paranoia, that Simonescu was a US spy, selling Romania's scientific secrets. His visa, needed to allow him to complete his autumn lectures at Yale, where he was still a visiting professor, was withdrawn. After pressure from US scientists and the US embassy, he was belated allowed to go. "It was a very scary time", he remembers, thinking it would be his last trip. But when he returned in January 1989, the revolution had changed everything.

There can be no comparison between conditions now and then, says Simonescu, even though the present is very far from ideal. Funds are now decreasing, not increasing. And although there is now complete freedom to travel, as often as not the young scientists who continue to be sent abroad for training no longer return. Indeed, some of those who resisted the temptation to defect during their periods abroad in the 1980 s now want to leave. "They do not complain that they cannot do good research here", says Simonescu; "It is mostly because the salaries are too low."

The Simonescus remain undaunted. Their strategy is to keep training new people, even if the returns are now likely to be lower.

Nicolae Simonescu is also devoting energy to encouraging reforms within the academy as a whole. He is also in charge of Romania's biotechnology programme and has arranged for a small amount of its funds to be set aside for competitive grants. This is, for the time being, the only example of competitive project money in Romania. 